\title{
Risk factors for asthma
}

\author{
Michele Miraglia del Giudice ${ }^{1 *}$, Annalisa Allegorico ${ }^{1}$, Giuseppe Parisi ${ }^{2}$, Francesca Galdo ${ }^{1}$, Emilia Alterio ${ }^{1}$, \\ Amalia Coronella', Giuseppina Campana', Cristiana Indolfi', Natja Valenti ${ }^{1}$, Sonia Di Prisco', Serena Caggiano', \\ Nunzia Maiello ${ }^{1}$
}

From 70th Congress of the Italian Society of Pediatrics, Joint National Meeting SIP, SICuPP, SITIP

Palermo, Italy. 11-14 June 2014

Asthma is the most common chronic respiratory disease of childhood, and even if there have been many advances in the understanding pathogenesis of the disease, many aspects remain to be clarified.

In the pathogenesis of asthma are involved both "protective" and "predisposing" factors as a result of the complex interactions that occur between genetic predisposition and environmental exposure.

From the genetic point of view, the identified genes responsible are more than 100 , and many polymorphisms have been shown to be associated to the onset of asthma, although none of these, alone or in combination, is able to predict the occurrence of disease.

The environmental factors most involved in the onset of asthma in children are represented by allergens, tobacco smoke, respiratory infections and air pollution.

Indoor allergens (dust mites, mold and animal dander) and outdoor (pollens and molds) are able to induce sensitization by prolonged exposure and trigger acute asthma. Allergic sensitization, in the concept of atopic march, represents a major risk factor for the development of asthma. In particular, the subjects polysensitized and with food allergy may present more severe asthma [1].

The exposure to cigarette smoke in both prenatal and postnatal increases the risk of the child becoming asthmatic and the asthma severity.

It has also noted recently that obesity is a risk factor for asthma because it causes an increase of leptin, TNF- $\alpha$, and IL-6, which exert a pro-inflammatory non-eosinophil action [2]. In addition, the lack of physical activity, for weight gain, contributes to the determinism of the disease [3].

\footnotetext{
* Correspondence: michele.miraglia@unina2.it

'Department of women and child and general and specialized surgery, Second University of Naples, Italy

Full list of author information is available at the end of the article
}

Vitamin D is involved in the processes of development and fetal lung maturation; the levels of $25-\mathrm{OH}$ vitamin $\mathrm{D}$ from umbilical cord blood are inversely correlated with the risk of respiratory infections and wheezing in childhood [4]. The vitamin D has immunomodulatory properties exerting an action of inhibiting the production of pro-inflammatory cytokines and induction of the synthesis of antimicrobial peptide on cells of the innate immune system [5]. The vitamin D modulates the effects of glucocorticoids and also has a role in bronchial remodeling, as it regulates the expression of genes of bronchial smooth muscle.

Infections early in life may play a role of "induction" of wheezing or "protection" against the development of allergic diseases (according to the hygiene hypothesis) [6-8]. In infants at risk viral respiratory infections can cause wheezing, which in turn can evolve later in asthma particularly in individuals with atopic predisposition.

\section{Authors' details}

'Department of women and child and general and specialized surgery, Second University of Naples, Italy. ${ }^{2}$ Rizzoli Hospital of Ischia, Naples, Italy.

\section{Published: 11 August 2014}

\section{References}

1. Simpson A, Tan VY, Winn J, Svensén M, Bishop CM, Heckerman DE, Buchan I, Custovic A: Beyond atopy: multiple patterns of sensitization in relation to asthma in a birth cohort study. Am J Respir Crit Care Med 2010, 181:1200-6.

2. Hjellvik V, Tverdal A, Furu K: Body mass index as predictor for asthma: a cohort study of 118,723 males and females. Eur Respir J 2010, 35:1235-42.

3. Devereux $G$, Seaton A: Diet as a risk factor for atopy and asthma. J Allergy Clin Immunol 2005, 115:1109-17.

4. Brehm JM, Schuemann B, Fuhlbrigge AL, Hollis BW, Strunk RC, Zeiger RS, Weiss ST, Litonjua AA, Childhood Asthma Management Program Research Group: Serum vitamin D levels and severe asthma exacerbations in the Childhood Asthma Management Program study. J Allergy Clin Immunol 2010, 126:52-58.

5. Bosse' Y, Lemire M, Poon AH, Daley D, He JQ, Sandford A, White JH, James AL, Musk AW, Palmer LJ, Raby BA, Weiss ST, Kosyrksyj AL, Becker A, 
Hudson TJ, Laprice C: Asthma and genes encoding components of the vitamin D pathway. Respir Res 2009, 10:98.

6. Scott M, Roberts G, Kurukulaaratchy RJ, Matthews S, Nove A, Arshad SH: Multifaceted allergen avoidance during infancy reduces asthma during childhood with the effect persisting until age 18 years. Thorax 2012, 67:1046-51.

7. Elliott L, Henderson J, Northstone K, Chiu GY, Dunson D, London SJ: Prospective study of breast-feeding in relation to wheeze, atopy, and bronchial hyperresponsiveness in the Avon Longitudinal Study of Parents and Children (ALSPAC). J Allergy Clin Immunol 2008, 122:49-54.

8. Visser CA, Garcia-Marcos L, Eggink J, Brand PL: Prevalence and risk factors of wheeze in Dutch infants in their first year of life. Pediatr Pulmonol 2010, 45:149-156.

doi:10.1186/1824-7288-40-S1-A77

Cite this article as: Miraglia del Giudice et al:: Risk factors for asthma.

Italian Journal of Pediatrics 2014 40(Suppl 1):A77.

\section{Submit your next manuscript to BioMed Central} and take full advantage of:

- Convenient online submission

- Thorough peer review

- No space constraints or color figure charges

- Immediate publication on acceptance

- Inclusion in PubMed, CAS, Scopus and Google Scholar

- Research which is freely available for redistribution

Submit your manuscript at www.biomedcentral.com/submit 